\title{
Understanding and designing nature experiences in cities: A framework for biophilic urbanism
}

Maibritt Pedersen Zari

Increasing evidence shows that creating and maintaining relationships with nature is important for human wellbeing. Humanity has become a mostly urbanised species where people typically spend most of their time indoors. It is important then that strategies for deliberately bringing aspects of nature into urban spaces are explored. Design that responds to an understanding of people's innate connection to the living world can be termed biophilic design. This research defines a unique biophilic urbanism framework for analysing and mapping biophilic urban elements. Thirty characteristics of biophilic cities were identified and then used to map Wellington, New Zealand. Observations arising from the research include: 1 / while access to wild nature might be an important characteristic of a biophilic city, planned design interventions are also significant; and 2/ when identified biophilic elements form part of a larger interconnected spatial experience through time, positive effects may be enhanced. This can enable identification of strategic locations for biophilic interventions in the wider urban fabric to facilitate more effective urban nature experiences. This suggests that biophilic urbanism must encompass a wide range of human sensory information, and should be designed from a four-dimensional (i.e. including time) perspective.

Keywords: biophilic design; urban design; urban nature; GIS mapping, Wellington, nature experience.

\subsection{Introduction: evidence of the benefit of human-nature relationships}

Human survival is dependent on ecosystems and the biodiversity they contain (Bastian et al., 2012). This is because the diverse range of organisms inhabiting the planet affect ecosystem processes and functions, and therefore ecosystem services (Brook et al., 2013, Norberg et al., 2012). Ecosystem services are the benefits that humans (and other living organisms) derive, either directly or indirectly from the functions of ecosystems (Potschin and Haines-Young, 2016). At the same time that global biodiversity loss has accelerated (Ceballos et al., 2015), humanity has become an urbanised species. The trend towards urbanisation is rapidly increasingly globally, particularly in developing nations, with the proportion of total urban dwellers on the planet set to reach more than $70 \%$ by 2050 (Zhang, 2016). Combined with this, urbanised people in developed countries tend to spend high proportions (up to 90\%) of time indoors (Matz et al., 2014). This has three important biodiversity-human relationship impications. Firstly, cities must be taken into account in terms of the large negative impact they have on biodiversity (Aronson et al., 2014). Secondly, because people are dependant on ecosystem services, which in part are supported by biodiversity, the abundance or lack of urban biodiversity directly impacts the majority of humans (Taylor and Hochuli, 2015). Finally, as urbanisation increases, cities tend to become more dense, and pressure on urban green spaces occurs. This means there is a risk that urban populations will experience negative psychologcal impacts due to a 'extinction of nature experience' (Botzat et al., 2016, Louv, 2008). It is then, vital to ensure that interior environments and indeed whole urban environments are designed, created and managed to enable meaningful human-nature connections (Turner et al., 2004). This last aspect of the nature-human relationship discussion is the main focus of this paper. 
An increasing body of international research details the benefits that arise when people have a direct or indirect relationship with the natural world (Ryan et al., 2014, Gillis and Gatersleben, 2015, Soderlund and Newman, 2015, Aerts et al., 2018). Although Hartig et al. (2014) urge caution regarding gaps in knowledge related to some of the benefits of contact to nature, evidence exists of positive physical benefits such as: reduced blood pressure and cortisol levels, increased parasympathetic nervous system activity, and reduction in overall stress (Tyrväinen et al., 2014, Li et al., 2011); increased immunity (Gullone, 2000, Ruebush, 2009); and increased cognitive ability (Berman et al., 2008). Evidence of psychological benefits includes: positively modified behaviour, particularly in terms of social interaction and reduced violence (Kuo and Sullivan, 2001, Faber Taylor et al., 2002); decreased rates of depression (Berman et al., 2012, Cohen-Cline et al., 2015); increased ability to concentrate (Hartig et al., 2003); increased happiness (Barton and Pretty, 2010); and increased social cohesion (Hartig et al., 2014). Soderlund and Newman (2015) expand upon the evidence of some of these nature-wellbeing relationships. Economically, introducing certain elements of nature into commercial buildings results in increased productivity and employee satisfaction (Browning et al., 2012). When applied to health care environments evidence suggests that time to recover from surgery or illness reduces (Ulrich, 1984).

Design that seeks to purposefully create human-nature relationships or uses these to increase human wellbeing can be termed 'biophilic design' (Kellert et al., 2008). 'Biophilia', meaning an innate love or attraction to the living world, was coined by psychologist E. Fromm in 1961 (Eckardt, 1992, Landis, 1975), was expanded upon by biologist E.O. Wilson in 1984 (Wilson, 1984), and developed further by social-ecologist S. Kellert and others (Kellert, 2005, Kellert et al., 2008, Kellert and Wilson, 1993). Browning et al. (2014) demonstrate how increased human wellbeing through nature exposure relates to specific biophilic design strategies. Biophilia, and consequently biophilic design, tend to consider the causes of health and wellbeing, rather than the causes of disease. This means a measure of the health and quality of the urban environment in terms of opportunities for human-nature relationships is important.

Cities that are examples of urban environments where human-nature relationships and opportunities for nature experiences clearly exist and are purposefully designed can be termed 'biophilic cities' (Beatley, 2011). These are cities where ecological restoration, architecture, landscape architecture, and urban planning are deliberately used to heighten the physical, psychological, and economic benefits that contact with nature can bring to city inhabitants (Beatley, 2016a, Beatley, 2018). In order to advance the practice of biophilic urban design, it is important to understand what kinds of urban conditions and interventions contribute to a biophilic city, and to examine how these might be related in time and space through spatial mapping techniques. This research reports therefore on the 'Wellington Nature in the City' project which mapped and analysed an existing city in terms of urban biophilic elements. The aim of the project was to produce replicable categorisations for mapping in other cities in terms of biophilia and urban nature relationships (Pedersen Zari, 2017). This was done in order to produce an investigation of the types, locations, and ranges of spatial design elements related to biophilic design, and so that strategic decision making regarding urban planning for increased wellbeing could be enhanced in the future. The research tests the concept that by mapping locations and types of biophilic elements in a city, 
relationships between biophilic elements in both space and time, as a person moves between biophilic sites can be examined and understood, and that mapping of biophilic urban elements can contribute to the development of biophilic urbanism tools and strategies.

\section{The Wellington Nature Map project}

\subsection{Research site and project background}

Wellington, New Zealand is a small city of approximately 200,000 residents. It is a coastal settlement located in the southern-most part of the North Island of New Zealand, and is a city of steep and often deep green, bush clad hills surrounding a large harbour. Mostly because of its setting and access to 'wild' nature, Wellington has been identified as a biophilic city, through the international Biophilic Cities Network (Beatley, 2016b). Partly in order to test the validity of the claim that Wellington is biophilic, this research set out to use GIS mapping techniques to determine specific areas, sites, and buildings that could be identified as either: sites of nature in the city; places where nature activities are possible; or places where the urban fabric reflects some sort of special cultural relationship to the land and sea. While the specific objectives of the mapping exercise were left deliberately open ended, the aim was to use geospatial techniques to investigate biophilic urbanism in Wellington while devising a biophilic urbanism framework that could be relevant in other urban contexts. The resulting online interactive publicly accessible map, termed 'The Wellington Nature in the City Map' (Pedersen Zari et al. 2017) was published online in 2017. It is a joint project between the Wellington City Council (WCC), Victoria University of Wellington's School of Architecture, and the Wellington Living Architecture group, with assistance from Victoria University's School of Geography, Environment and Earth Sciences.

\subsection{Biophilic Urbanism Framework}

Various researchers have defined biophilic design elements in architectural and interior architecture contexts (Kellert, 2005, Kellert et al., 2008, Ryan et al., 2014, Kellert and Calabrese, 2015) and in urban settings (Beatley, 2011). In order to devise a suitable framework to enable physical mapping of actual biophilic sites or elements of a city, a unique biophilic cities framework had to be formulated however. The resulting biophilic urbanism framework identifies and categorises 30 unique characteristics of biophilic cities (tables 1-3). These categories were defined primarily by comparing combinations of aspects of cities deemed important in creating relationships between people and nature as defined by Beatley (2011, 2016a). This was in combination with understandings of more abstracted notions of human-nature related spatial design that are applied at the building or interior architecture scale as elaborated upon by Kellert et al. (2008) and Browning et al. (2014). It is important to consider both urban design and architectural aspects of biophilic design within a biophilic urbanism framework, because the human experience of a city is a complex and seamless series of interactions in space and time at different scales, as the body and its sensory perception systems move in, out and around other humans, vehicles, buildings, infrastructure, urban spaces, and whole landscapes. Until the creation of the biophilic urbanism framework, a way to describe and understand biophilic spatial design simply and across the various scales 
of urban contexts (from the human body itself and single 'room', through to streetscape, neighbourhood, and the regional) was difficult to find.

\subsubsection{Nature in the city - biophilic conditions and infrastructure}

The Nature in the City category addresses the physical, ephemeral, and virtual presence of nature in urban environments. This includes plant life, water, and animals, as well as sounds, scents, light, wind, and other natural elements. As discussed in the introduction, incorporating nature, both designed and wild into cities has numerous measurable benefits to human wellbeing (Jorgensen and Gobster, 2010, Lee and Maheswaran, 2011, Carrus et al., 2015). Even in cases where some causal relationships between human psychological wellbeing and nature experiences are not yet well understood, urban green space is acknowledged to be of great importance to public mental health (Grahn and Stigsdotter, 2010). Incorporating nature into cities also has vital urban sustainability benefits including: increased urban biodiversity and ecosystem services provision (Rastandeh et al., 2018); climate change mitigation and adaptation (Gill et al., 2007, Pedersen Zari, 2018); cleaner air and cooler temperatures (Zupancic et al., 2015); and cleaner and more manageable water flows (Donovan, 2017, Samson et al., 2017). These ecological benefits are intimately linked to human wellbeing (Millennium Ecosystem Assessment, 2005) and positively reinforce the psychological benefit of nature inclusion into urban settings, particularly if both ecological function and psychological benefit are equally motivating factors in design. Table 1 elaborates on the different elements included in the Nature in the City category.

\subsubsection{Nature activities - learning about and interacting with nature in the city}

A biophilic city has activities for residents and visitors alike that enable connection with and enjoyment of nature, that encourage learning about the specific nature of that place, that keep ecosystems healthy or regenerate them, and enable participation in outdoor activities or nature experiences (Beatley, 2011). Such activities demonstrate in part how important or celebrated nature is to a city and its residents, and suggest that biophilic cites cannot be measured just by the amount of nature in them, but should also be thought of in terms of how people feel about or perceive nature and opportunities for human-nature connection.

Evidence suggests that when people experience a loss of interaction with nature this reduces positive attitudes, and behavior towards the living world (Soga and Gaston, 2016). By enabling urban dwellers to have opportunities to access nature, wild places, and other biophilic spaces or elements in an urban setting, increased physical and psychological wellbeing can occur along with a greater understanding of ecological values and the value of local and global nature (Mitchell et al., 2016, Bijker and Sijtsma, 2017, Douglas et al., 2018). Table 2 details elements in the Nature Activities category.

\subsubsection{Nature of spaces and places - designed biophilic buildings and spaces}

The Nature of Space and Places category relates to how certain kinds of spaces or spatial relationships in buildings, between buildings, or in urban spaces relate to configurations in nature that can cause people to have positive physical or psychological reactions (Kellert et al., 2008). This includes the innate need and desire to be able to see beyond immediate surroundings, or to be able to get an overview of a space from up high; ability to retreat to 
places that feel safe; interest in the thrilling or slightly dangerous; and curiosity to explore spaces that may be partially hidden (Hagerhall, 2000, Ryan et al., 2014). This category also includes buildings or spaces that enable people to connect to or understand the surrounding climate, geography, and ecology through techniques such as: passive heating, cooling, and ventilation (Crosbie, 1998); access to natural daylight and views (Joarder et al., 2010); and bioclimatic design, where buildings are designed to work with the site and climate they are located in (Olgyay, 2015). Table 3 shows elements in the Nature of Spaces and Places category.

Table 1. Nature in the city - biophilic conditions and infrastructure

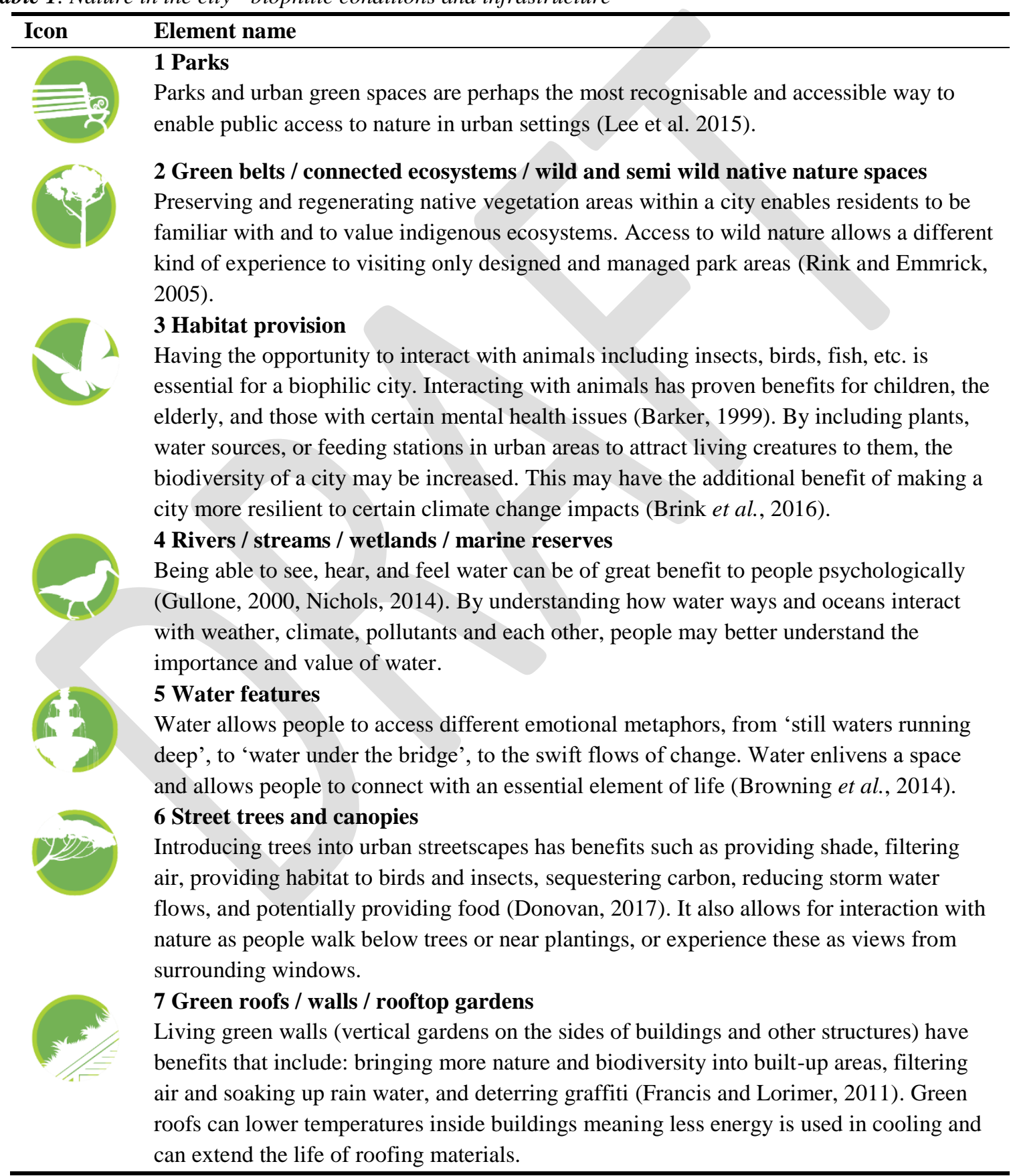




8 Community gardens / edible landscaping
Engaging in food growing, foraging, or harvesting in urban settings has significant
benefits in terms of sustainability and human health, and may enable deeper relationships
to form between people and nature (Viljoen and Howe, 2012).
9 Nonvisual and virtual nature
Sounds, smells, tastes, and things people can feel or touch engage the senses beyond just
sight. This sensory information, particularly that from 'nature', is processed in a different
way by the human brain. This can in turn increase cognitive performance, aid in
relaxation and lowering of blood pressure, and have other positive effects (Browning $e$ t
al., 2014). Contact with virtual nature, or representations of nature is also included in this
category as an important aspect of urban biophilic design (Downton et al.).
10 Sensory stimuli
When people experience surprising movements, or sounds that are not predictable timing
wise, this can be positive physically as well as psychologically. Examples include leaves
falling off trees, objects moved in a breeze, ripples on water, birds flying past etc. These
random movements can temporarily delight and distract, usually on a subconscious level,
and can increase the ability to concentrate for longer periods. Such movement can also
facilitate relaxation of the eye (Browning et al., 2014).

Table 2. Nature activities - learning about and interacting with nature in the city

Element name
Support for groups that focus socialisation, learning, or exercise around outdoor activities
enable people to get outside, enjoy, and learn about nature aspects of the city. Such groups
may range from tramping and jogging clubs, to gardening and outdoor meditation groups.
2 Outdoor activity centres / sports fields / places to swim
Facilities for outdoor activities, including sports, swimming, and 'messy play', enable
people to interact with the climate and ecology of the city.
3 Camping grounds
Opportunities to sleep outside and experience camping enable people to connect to nature
in a way that is different to typical dwelling situations.
$\mathbf{4}$ Pedestrian zones / bike paths / tramping walkways
A city with dedicated spaces for people to walk or bike rather than use cars, both in high
density parts of the city and in more 'wild' areas, not only enables this kind of activity to
happen, but it sends a signal to people to engage more with the outdoors.
5 Gathering spaces in nature / playgrounds
Places in the city where people can gather outdoors for private or public events, and
where there are dedicated facilities such as toilets, bbqs, or playgrounds, normalise being
outside and experiencing different climatic conditions while learning more about the
ecology of the region.
6 Cafes / restaurants with outdoor spaces
Cafes and restaurants that offer outdoor spaces allow people to be outside on fine days
and to enjoy the climate while experiencing the urban environment.
$\mathbf{7}$ Natural history museums / botanical gardens / environmental education initiatives
Museum and education facilities dedicated to preserving and learning about a city's
natural heritage, ecological history, present condition, and indigenous flora and fauna are
part of ensuring citizens understand and value their ecological setting.




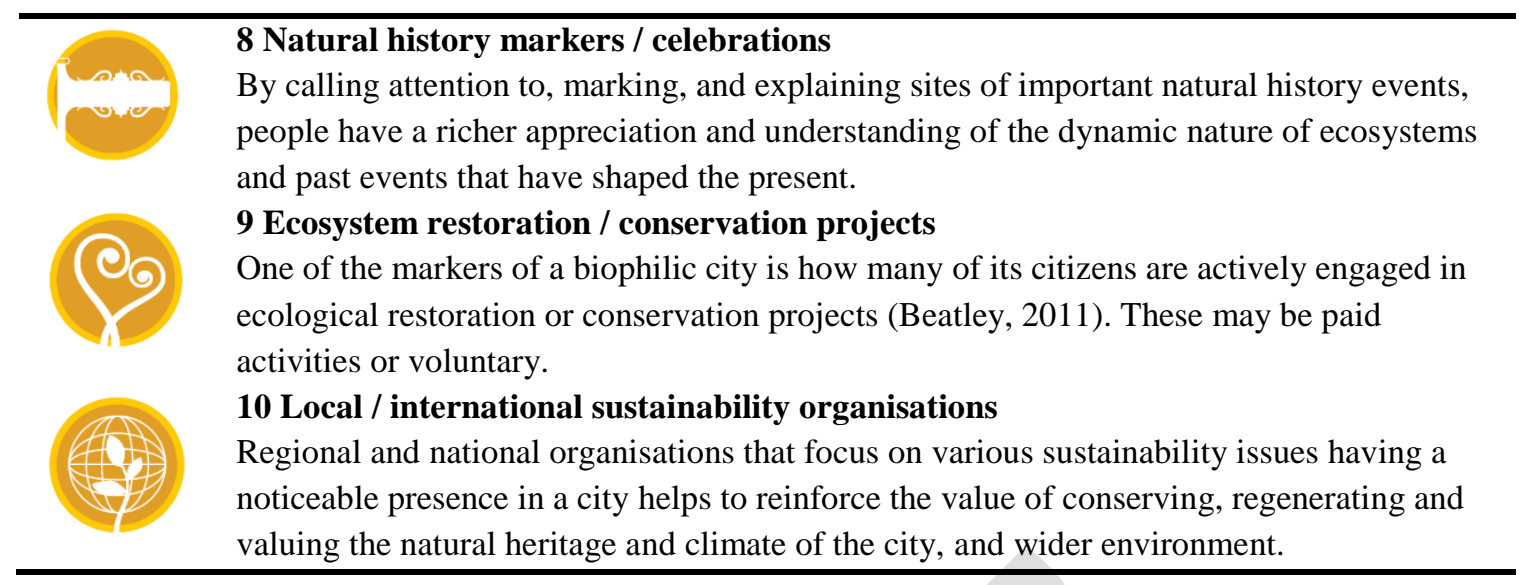

Table 3. Nature of spaces and places - designed biophilic buildings and spaces

\begin{tabular}{|c|c|}
\hline Icon & Element name \\
\hline & 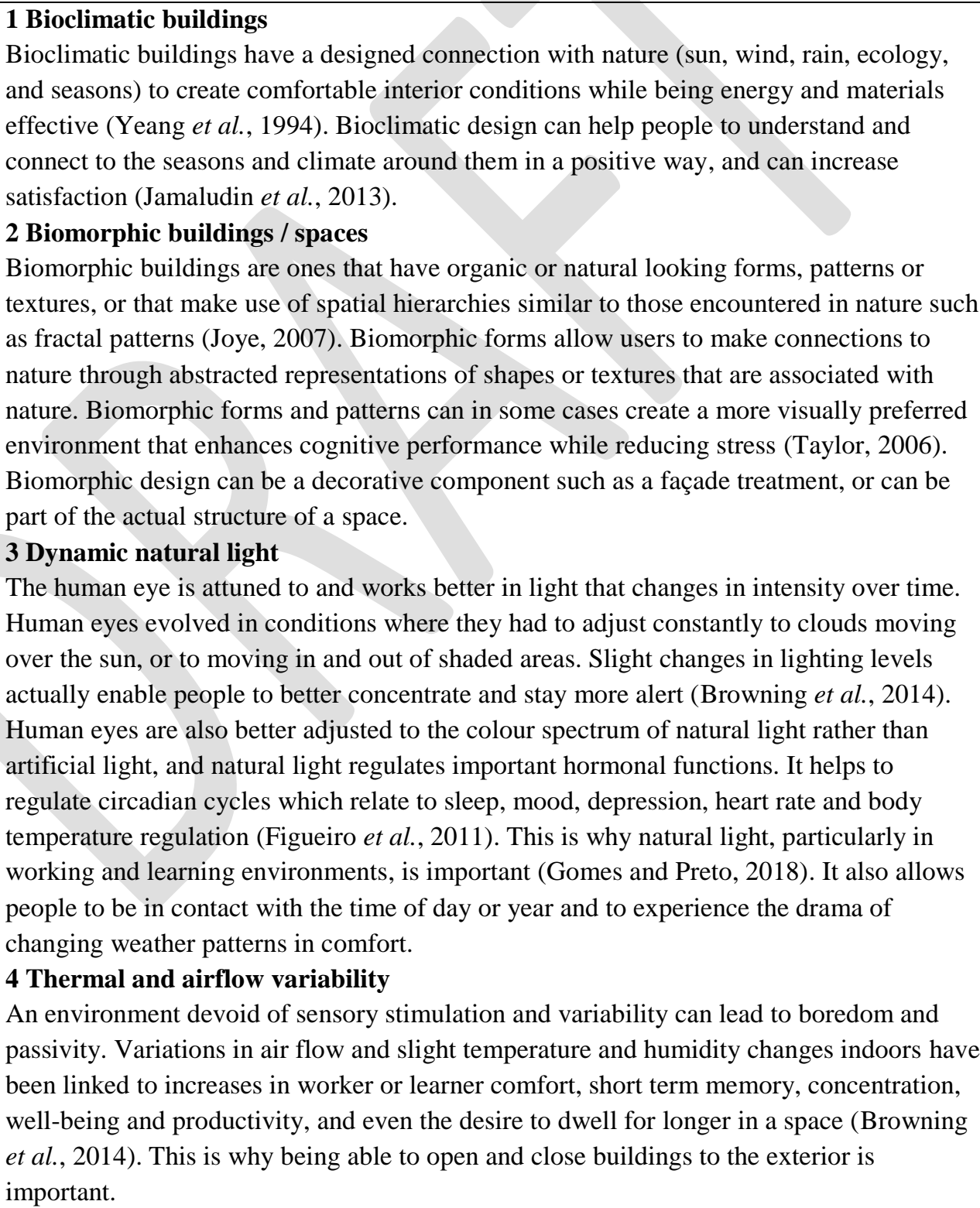 \\
\hline
\end{tabular}




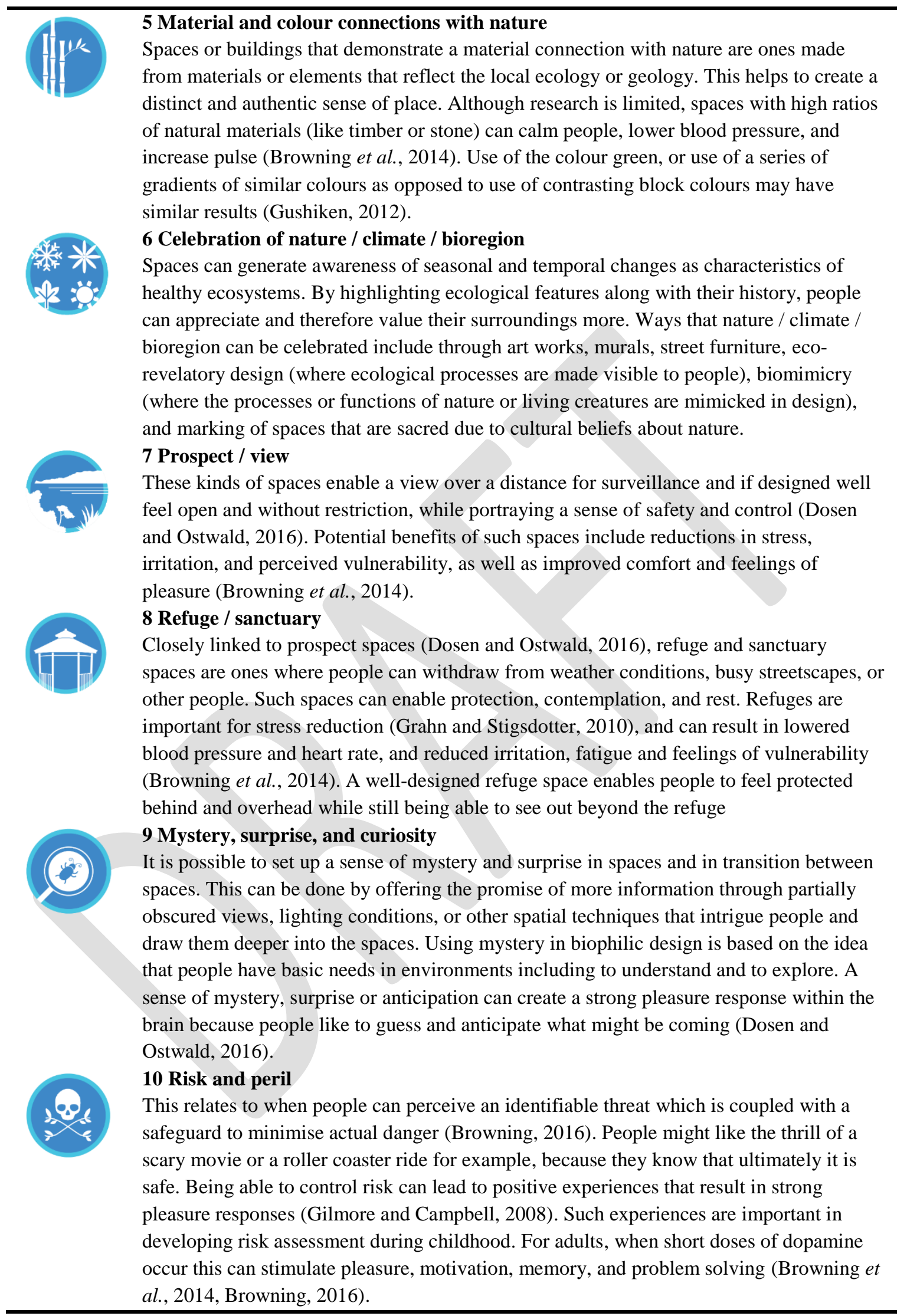




\subsection{Geographic information system (GIS) mapping and Story Maps}

After the biophilic categories were determined, the team worked with a specially designed GIS mapping application to locate the approximately 170 biophilic locations shown on the map with global positioning system (GPS) coordinates. Locations were determined thorough: reviewing existing resources and guides relating to Wellington's urban nature including WCC park and trail guides, and other reports and information about urban green and blue space and outdoor activities; conducting field surveys and transect walks (as described by Melemis and Tixier, 2014); and by utilising the local research team's own knowledge. This latter point was important, particularly in relation to understanding the nature of some of the city's buildings and the interiors of these which are often not discussed in published literature. This indicates that replicating biophilic urban elements mapping in other urban centres will need to include literature reviews, but also field work and engagement with city residents. This field work and engagement with local people will need to be tailored to both the spatial and cultural context of the city.

The intention of the Wellington Nature in the City Map project was not to identify and locate every possible biophilic element of the city, but to focus on elements that were publicly accessible and primarily were in the inner-city area (as defined by New Zealand census area units, 2013). The inner city is largely made up of the flatter land between the ocean and the steep green hills that surround it. Elements that were mapped tended to be those that are well-known or iconic to Wellington (defined in part through literature review and through local knowledge), and ones that aided in demonstrating a range of examples of each category. Locations were documented through written summary, photography, and where appropriate video.

Once the data had been collected, it was entered into the ArcGIS environment and linked with the Environmental Systems Research Institute (ESRI) 'Story Map' software system. Story Maps combine maps and other GIS information with narrative text, images, and multimedia content in order to explain, enhance, and navigate maps (Alemy et al., 2017). Combining narrative techniques with geo-spatial mapping is increasingly part of people's navigation experience of modern life, and reflects several global converging trends, such as increased citizen geo-awareness, and fast evolving geo-technologies and sharing systems (Kerski, 2015). These trends are likely to continue to rapidly change how people understand and experience the world around them, particularly as portable digital technologies also evolve (Kerski, 2015). Evidence suggests that the use of ESRI story maps may have positive influence on people's participation in sustainability related activities and in understanding urban health issues (Sui and Cinnamon, 2016, Austin, 2018). In the case of the Wellington Nature in the City Map, the use of the Story Map software was deemed necessary by WCC in order to fit in with other WCC funded projects and their existing website structure. If the biophilic urban mapping conducted in Wellington is replicated in other urban settings, beginning with an examination of the suitability of Story Maps or other geospatial narrative programmes is recommended. This should be done in order to find a mapping interface and platform that is appropriate to the cultural context of the city in question.

The Wellington Nature Map Story Map is organised into sections following the biophilic urbanism framework (tables 1-3) with a final combined section that overlays all of the mapped elements onto a single map. This demonstrates where clusters of biophilic 
elements exist in Wellington, and may in the future enable planning of routes to more effectively experience Wellington as a biophilic city (figure 1).

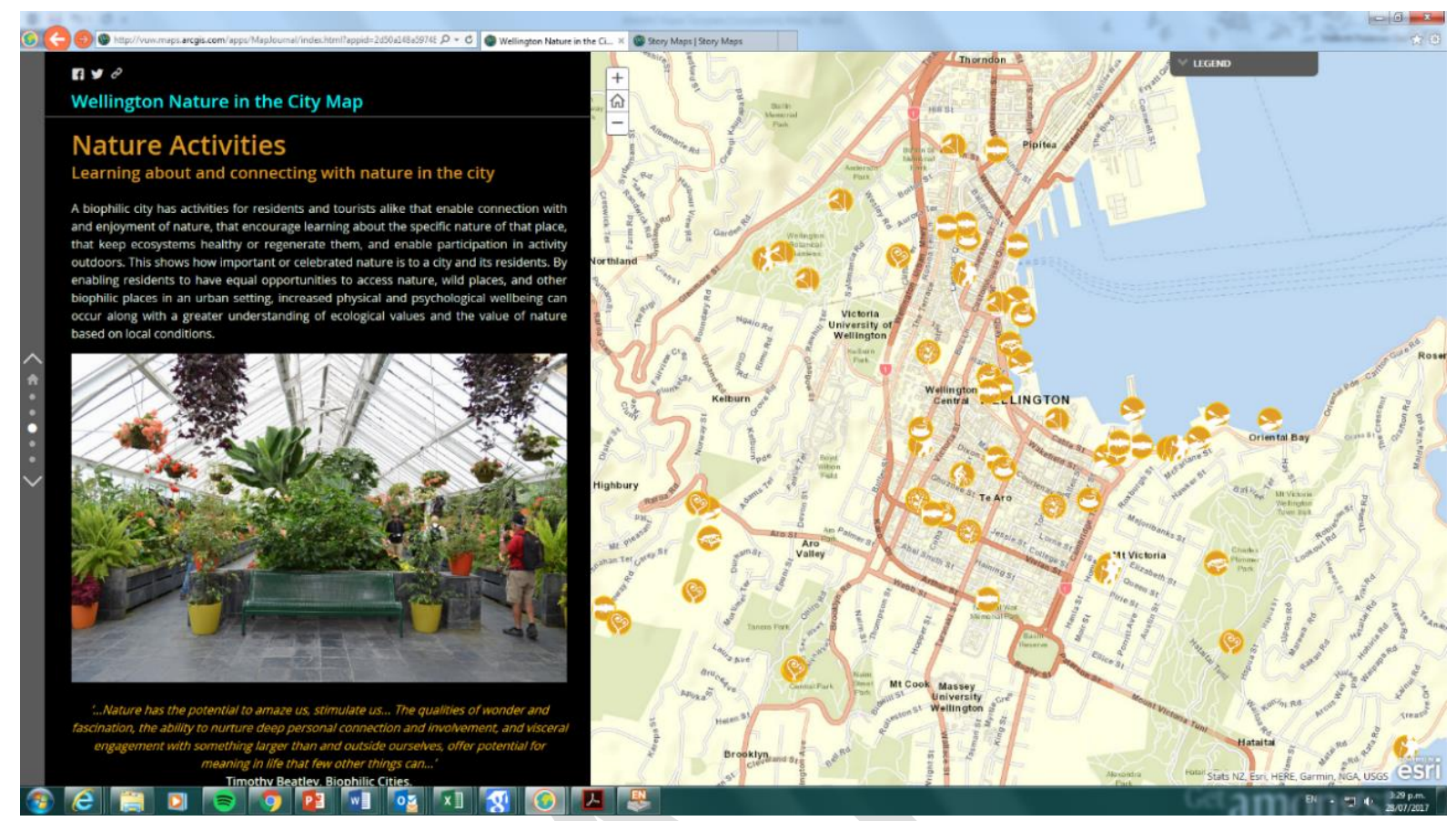

Figure 1. Screen shot of the online Wellington Nature Map

When an icon on the map is selected, a pop-up text and image box appears for each site. This displays a brief explanation for each location including: a written description and history; relevance of the site to human-nature relationships; images and video clips where possible; and links to relevant further information, groups, or people. The map is being added to as the city evolves and as city residents or visitors interact with it. On the online map people are encouraged to write to the research team with ideas of new biophilic elements that could be added to the map.

\subsection{Findings and observations related to the Wellington Nature Map project}

Mapping specific biophilic features of Wellington has proven to be one way to demonstrate that Wellington is likely to be a city that has enhanced human wellbeing attributes because of opportunities afforded for human-nature relationships and connections to occur. This is in part because of the geography and surrounding ecosystems of the city itself. Because Wellington is a complex folded landscape that surrounds a harbour and is in turn surrounded by bush or green spaces to a large extent, many residents have elevated views of nature from homes and workplaces. These unplanned biophilic aspects of Wellington relate largely to the Nature in the City category of biophilic elements (green icons - table 1), and in particular: green belts / connected ecosystems / wild and semi wild native nature spaces; habitat provision; rivers / streams / wetland / marine reserves; and nonvisual nature. These green icons on the Wellington Nature in the City Map, appeared to be the most common of the three categories and may illustrate that tangible literal inclusion of nature into the city is likely to be the easiest aspect of biophilic urbanism to both map and understand. Having a large amount of living ecosystems in the city is probably an important part of Wellington 
being deemed 'biophilic'. Related to this, and demonstrated by the large number of mapped nature activities sites (yellow icons), the research shows that an abundance of nearby wild nature may be important to the creation of a biophilic city because of its relationship to the evolution of outdoor or nature-based activities residents can participate in.

It should be noted that many aspects of the nature in the city elements (table 1), and all of the other two categories of biophilic city elements (tables 2 and 3) are aspects of Wellington that are deliberately planned, encouraged, and patronised by the citizens, managers, and leaders of the city. Aspects of the city such as the abundance of outdoor activities available to residents, the large number of volunteer driven regeneration projects, and the active celebration of natural history sites, demonstrate that Wellington being biophilic is not just an accident of geography but is also due to the actions of citizens and public support for nature related activities, groups, sites etc.

The most difficult to find category of elements, and consequently perhaps the least abundant on the map, related to the nature of spaces and places category (the blue icons). These relate to deliberate acts of designing spaces and buildings that reflect or create humannature relationships. Typically, these are buildings or designed urban outdoor spaces. It is of note that many (but certainly not all) of the sites and places that were mapped as belonging to the nature of spaces and places category are among some of Wellington's newer buildings and spaces. Perhaps this reflects a changing attitude toward nature in the city, to architectural and urban design, or to an evolving Wellington identity or sense of place that relates to human-nature connections in the city. The special relationship of Wellington to wild nature, sea, and wind has been described as an important part of its residents' identities and likely relates to Tangata Whenua (indigenous Māori) concepts of the living elements of nature and guardianship of these (Waterfront Leadership Group, 2001, Wellington City Council, 2003, McIntosh et al., 2018).

Spatially, there are clear clusters of biophilic elements in the city. Unsurprisingly these relate to some of the large wildlife reserves and botanical gardens to the west of the city (Zealandia, Otari-Wilton's Bush, and the Botanic Gardens), to the inner and outer green belts, and to southern coastal zones, particularly in the Taputeranga Marine Reserve. More densely urban biophilic zones also exist. These tend to centre around heavily visited and culturally significant parts of the city. One central city biophilic zone centres in the Civic Square area of the city, which is often thought of as the heart of Wellington City. This zone is a combination of street plantings, urban parks, public art works, and markers of natural history. Another biophilic zone centres around lower Lambton Quay and the parliament buildings. This zone is created through the presence of various nature related public art works, biomorphic buildings, and urban green spaces. A third zone, which connects the first two, stretches along most of the waterfront area from the local ferry terminals to Oriental Parade. This zone is a collection of biophilic urban outdoor features such as bridges, lagoons, beaches, sites of outdoor activities, and several of the city's natural history museums (figure 2). 


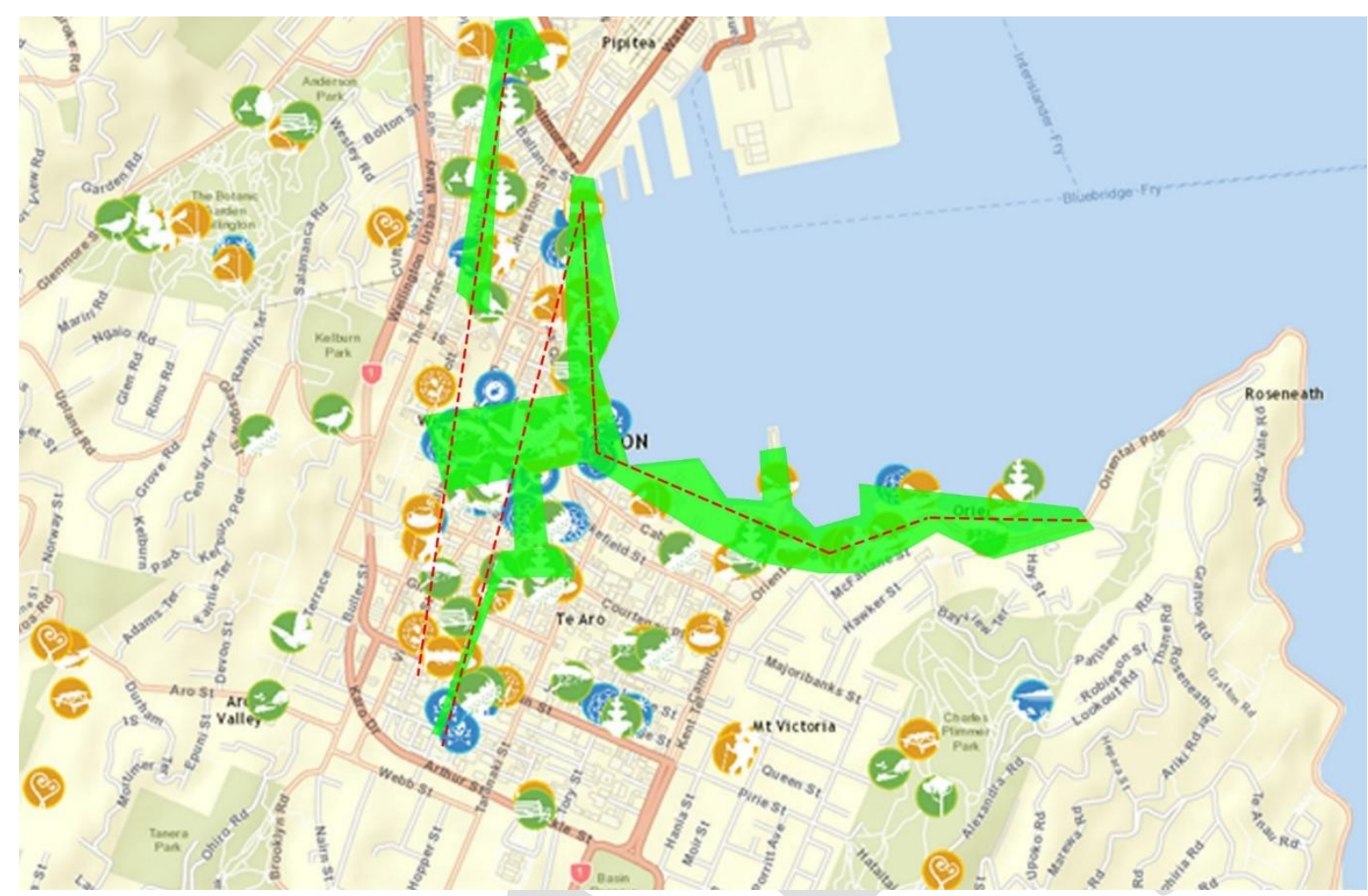

Figure 2. Zones (green) and corridors (red lines) of clusters of inner city biophilic elements in Wellington

\subsection{Discussion}

Observations arising from the Wellington biophilic urban elements mapping project suggest that the spatial design and materiality of buildings and their facades, as well as public works of art and soundscapes, impact on urban biophilic experiences. Specific cultural interpretations of nature and human-nature relationships are also likely to be important. The quality and variety of biophilic elements, as well as accessibility to them in linked spatial experiences through time is likely to be important in the creation of a biophilic city, as well as simply a measurable quantity of trees or urban green space. Urban biophilic experience therefore is more complex and holistic than simply the amount of nature in a city.

Cities are perceived from different heights and speeds in different lighting, temperature, and weather conditions, and through different cultural lenses. Biophilic design is a distributed system therefore (Downton et al., 2016), rather than a set of disconnected points in space. A key implication of this for designers seeking to increase biophilic experiences in cities, or to further the use of biophilic urban mapping, is that spatial data related to demographics and movement of people in cities is required, rather than just knowledge of where existing biophilic elements are. Useful spatial data could include:

1. Where people tend to rest or gather in the city, how these places are connected, and how people move between them.

2. How people move about the city, at what speed they do this, and what the main transport routes or hubs are, particularly those that are pedestrian and cycling oriented. Also of interest is how pedestrian oriented spaces and vehicle oriented transport corridors relate to each other and interact. 
3. How people's movement, resting, and gathering behaviours are affected by diurnal, seasonal, and climatic variations.

4. How nature experiences vary between different groups in a city's particular cultural context and how accessible green or blue urban spaces are to different demographic groups.

If this data is spatialised and overlaid onto maps showing where existing biophilic elements are in a city, strategic decisions about where to include additional biophilic elements in a city, how these can be connected together through dedicated pedestrian zones or green corridors, and when they should be implemented may be more effectively made. In existing cities, increased biophilic experiences will need to evolve over time. Understanding where confluences of biophilic elements or spaces exist, and where they are absent or too far apart in a city can indicate where biophilic interventions are needed that could create human wellbeing benefits. It is not within the realm of this research to be able to give exact numbers or areas of biophilic elements that should be present in an urban area for optimum human wellbeing. However, analysing maps such as the Wellington Nature in the City Map to give an indication of where areas of biophilic experience deprivation may exist could be a first step in determining where new biophilic interventions should be placed in a city. For example, where mapping indicates that an area of a city has few biophilic elements in it, this could be used to argue for additional biophilic interventions in the space, particularly if paired with demographic information related to population density and potential population growth in that area. Conversely, if an urban biophilia map shows that a cluster of biophilic elements already exist, urban designers or planners may use this to determine how this cluster can be added to or how these elements can be linked together through determined pathways, pedestrian zones, cycle routes etc.

\subsection{Conclusions}

The Wellington Nature in the City Map is a first step in investigating the presence and effects of biophilic design in Wellington. The approach taken suggests a potential new narrative in terms of understanding and planning for biophilic cities in general and could be a starting point for other biophilic urbanists to explore design opportunities. Major questions raised by the research include: 1/ how can cultural diversity and the differences between the preferences or needs of various groups of people be more effectively explored and integrated in biophilic design practice?; 2/ how do notions of experience through time influence understandings and experiences of biophilia, and then translate into new ways of designing urban biophilic experiences?; and 3/ how can mapping of biophilic urban elements be used to suggest, strengthen, or create biophilic routes through a city?

Because literature shows that experiencing and valuing nature-human relationships differs between various cultural groups (Sangha et al., 2018, Sangha et al., 2019, Chan et al., 2016), future research will include investigation of how the Wellington Nature in the City Map can be improved and used to capture differences in nature experiences among different cultural groups in the population, and then if desirable, increase these. Additional research could also include observation and survey of how people use the Wellington Nature in the 
City Map and examination of how its use has (or has not) altered perceptions of the city or of human-nature relationships. Citizens could for example be interviewed to ascertain which categories or elements of urban biophilia they consider more important and if they experience a lack of biophilic elements or nature experiences in certain parts of the city. This information could be cross referenced with the map to understand more fully if citizen experience is based on a presence or lack of biophilic design elements or possibly other factors such as a lack of knowledge that these elements are present, or a lack of access to them. This example demonstrates that the map itself could become an important communication medium in future research.

The biophilic urbanism framework devised for the Wellington Nature in the City Map is transferable to other cities but should be tailored to specific urban cultural, climatic, and ecological contexts. The biophilic urbanism framework and the Wellington Nature in the City Map itself are currently being utilised in the development of a similar biophilic elements map for Phoenix City in the Unites States of America (Knudsen, 2017). Mapping the biophilic urban elements of other cities that are part of the Biophilic Cities Network, and using control cities which are not, may enable identification of cities that are biophilic even if not selfidentified through the Biophilic Cities Network. This could also enable further geospatial investigations related to cities of different sizes, in different climates, and with different demographics, ecological features, and cultural systems related to a biophilic design agenda. Such discussions could contribute to further research investigating biophilic cities and their benefits or impacts on human wellbeing and the relationship (or not) of biophilic design to the overall ecological health of urban areas.

To conclude, biophilic design should not be seen as a panacea on its own in terms of sustainable cities. The nature of biophilic design is inherently human-centric and focused on the wellbeing outcomes of design for humans. Findings from biophilia focused research and design could however be an important contributor to a more holistic notion of ecological urban sustainability. That is, an idea and practice of urbanism that includes notions of urban ecology; climate change mitigation and adaptation; design for increased urban biodiversity and urban ecosystems; and crucially, through the concept of biophilia, the psychological (re)integration of people into nature itself. This is of great importance for safeguarding both the physical and psychological wellbeing of individuals and communities in the coming decades as humanity increasingly becomes urbanised and removed from outdoor environments, while concurrently people must learn how to create, adapt, and live in urban environments in a greatly changed ecological and climatic context.

\section{Acknowledgements}

Funding for the Wellington Nature Map from the Wellington City Council is gratefully acknowledged. Dr M. de Roiste (Victoria University of Wellington) provided technical assistance in relation to the GIS and Story Map process. Research assistance and photography was provided by R. Whale (Wellington Living Architecture), E. Cruz (École Centrale de Lyon), and K. Milne (Victoria University of Wellington). Icons were developed by K. Spencer (Kelly Spencer Graphic Design). 


\section{References}

Aerts, R., Honnay, O. \& Van Nieuwenhuyse, A., 2018. Biodiversity and human health: mechanisms and evidence of the positive health effects of diversity in nature and green spaces. British Medical Bulletin, 127, 5-22.

Alemy, A., Hudzik, S. \& Matthews, C.N., 2017. Creating a User-Friendly Interactive Interpretive Resource with ESRI's ArcGIS Story Map Program. Historical Archaeology, 51, 288-297.

Aronson, M., Sorte, F., Nilon, C., Katti, M., Goddard, M., Lepczyk, C., Warren, P., Williams, N., Cilliers, S., Clarkson, B., Dobbs, C., Dolan, R., Hedblom, M., Klotz, S., Kooijmans, J., Kühn, I., Macgregor-Fors, I., Mcdonnell, M., Mörtberg, U., Pyšek, P., Siebert, S., Sushinsky, J., Werner, P. \& Winter, M. 2014. A global analysis of the impacts of urbanization on bird and plant diversity reveals key anthropogenic drivers. Proceeding of the Royal Society B, 281, 20133330.

Austin, B.G., 2018. Investigating the Influence of Esri Story Map Design on Partcipation in Sustainability-Related Activities. Paper 2571. Western Kentucky University. https://digitalcommons.wku.edu/theses/2571.

Barker, S.B., 1999. Therapeutic aspects of the human-companion animal interaction. Psychiatric Times, 16, 4546.

Barton, J. \& Pretty, J., 2010. What is the best dose of nature and green exercise for improving mental health? A multi-study analysis. Environmental Science \& Technology, 44, 3947-3955.

Bastian, O., Haase, D. \& Grunewald, K. 2012. Ecosystem properties, potentials and services - The EPPS conceptual framework and an urban application example. Ecological Indicators, 21, 7-16.

Beatley, T., 2011. Biophilic Cities: Integrating Nature into Urban Design and Planning. Washington D.C: Island Press.

Beatley, T., 2016a. Planning for biophilic cities: From theory to practice. Planning Theory \& Practice, 17, 295300

Beatley, T., 2016b. Wellington, New Zealand: From Town Belt to Blue Belt. Handbook of Biophilic City Planning and Design. Springer, 75-84.

Beatley, T., 2018. Blue Biophilic Cities. Cham: Palgrave Macmillan.

Berman, M.G., Jonides, J. \& Kaplan, S., 2008. The cognitive benefits of interacting with nature. Psychological Science, 19, 1207-1212.

Berman, M.G., Kross, E., Krpan, K.M., Askren, M.K., Burson, A., Deldin, P.J., Kaplan, S., Sherdell, L., Gotlib, I.H. \& Jonides, J., 2012. Interacting with nature improves cognition and affect for individuals with depression. Journal of Affective Disorders, 140, 300-305.

Bijker, R.A. \& Sijtsma, F.J., 2017. A portfolio of natural places: Using a participatory GIS tool to compare the appreciation and use of green spaces inside and outside urban areas by urban residents. Landscape and Urban Planning, 158, 155-165.

Botzat, A., Fischer, L. K. \& Kowarik, I. 2016. Unexploited opportunities in understanding liveable and biodiverse cities. A review on urban biodiversity perception and valuation. Global Environmental Change, 39, 220233.

Brink, E., Aalders, T., Ádám, D., Feller, R., Henselek, Y., Hoffmann, A., Ibe, K., Matthey-Doret, A., Meyer, M., Negrut, N.L., Rau, A.-L., Riewerts, B., Von Schuckmann, L., Törnros, S., Von Wehrden, H., Abson, D.J. \& Wamsler, C., 2016. Cascades of green: A review of ecosystem-based adaptation in urban areas. Global Environmental Change, 36, 111-123.

Brook, B., Ellis, E., Perring, M., Mackay, A. \& Blomqvist, L. 2013. Does the terrestrial biosphere have planetary tipping points? Trends in Ecology \& Evolution, 28, 396-401.

Browning, W., 2016. Biophilia, buildings, and your brain. People and Strategy, 39, 8.

Browning, W., Kallianpurkar, N., Ryan, C., Labruto, L., Watson, S. \& Knop, T., 2012. The Economics of Biophilia. New York: Terrapin Bright Green.

Browning, W., Ryan, C. \& Clancy, J., 2014. 14 Patterns Of Biophilic Design. New York: Terrapin Bright Green.

Carrus, G., Scopelliti, M., Lafortezza, R., Colangelo, G., Ferrini, F., Salbitano, F., Agrimi, M., Portoghesi, L., Semenzato, P. \& Sanesi, G., 2015. Go greener, feel better? The positive effects of biodiversity on the well-being of individuals visiting urban and peri-urban green areas. Landscape and Urban Planning, 134, 221-228.

Ceballos, P.R. Ehrlich, A.D. Barnosky, A. García, R.M. Pringle \& T.M. Palmer 2015. Accelerated modern human-induced species losses: Entering the sixth mass extinction. Science Advances, 1, 1-5. 
Chan, K. M., Balvanera, P., Benessaiah, K., Chapman, M., Díaz, S., Gómez-Baggethun, E., Gould, R., Hannahs, N., Jax, K. \& Klain, S. 2016. Opinion: Why protect nature? Rethinking values and the environment. Proceedings of the National Academy of Sciences, 113, 1462-1465.

Cohen-Cline, H., Turkheimer, E. \& Duncan, G.E., 2015. Access to green space, physical activity and mental health: a twin study. Journal of Epidemiology and Community Health, 69, 523.

Crosbie, M.J., 1998. The Passive Solar Design and Construction Handbook. New York: John Wiley \& Sons.

Donovan, G.H., 2017. Including public-health benefits of trees in urban-forestry decision making. Urban Forestry \& Urban Greening, 22, 120-123.

Dosen, A.S. \& Ostwald, M.J., 2016. Evidence for prospect-refuge theory: A meta-analysis of the findings of environmental preference research. City, Territory and Architecture, 3, 4.

Douglas, O., Russell, P. \& Scott, M., 2018. Positive perceptions of green and open space as predictors of neighbourhood quality of life: Implications for urban planning across the city region. Journal of Environmental Planning and Management, 1-21.

Downton, P., Jones, D. \& Zeunert, J., 2016. Biophilia in urban design: Patterns and principles for smart Australian cities. Smart Cities for 21st Century Australia: Proceedings of the 9th International Urban Design Conference (IUDC), 7-9 November, Canberra, Australia. Association for Sustainability in Business, 168182.

Eckardt, M. H. 1992. Fromm's concept of biophilia. Journal of the American Academy of Psychoanalysis, 20, 233-240.

Faber Taylor, A., Kuo, F.E. \& Sullivan, W.C., 2002. Views of nature and self discipline: Evidence from inner city children. Journal of Environmental Psychology, 22, 49-63.

Figueiro, M.G., Brons, J.A., Plitnick, B., Donlan, B., Leslie, R.P. \& Rea, M.S., 2011. Measuring circadian light and its impact on adolescents. Lighting Research \& Technology, 43, 201-215.

Francis, R.A. \& Lorimer, J., 2011. Urban reconciliation ecology: The potential of living roofs and walls. Journal of Environmental Management, 92, 1429-1437.

Gill, S.E., Handley, J.F., Ennos, A.R. \& Pauleit, S., 2007. Adapting cities for climate change: The role of the green infrastructure. Built Environment, 33, 115-133.

Gillis, K. \& Gatersleben, B., 2015. A review of psychological literature on the health and wellbeing benefits of biophilic design. Buildings, 5, 948-963.

Gilmore, L. \& Campbell, M., 2008. Scared but loving it: Children's enjoyment of fear as a diagnostic marker of anxiety? The Australian Educational and Developmental Psychologist, 25, 24-31.

Gomes, C.C. \& Preto, S., 2018. Should an artificial window substitute a natural one? In T. Ahram \& W. Karwowski. Proceedings of the International Conference on Applied Human Factors and Ergonomics. Cham: Springer, 247-258.

Grahn, P. \& Stigsdotter, U.K., 2010. The relation between perceived sensory dimensions of urban green space and stress restoration. Landscape and Urban Planning, 94, 264-275.

Gullone, E., 2000. The Biophilia Hypothesis and life in the 21st Century: Increasing mental health or increasing pathology? Journal of Happiness Studies, 1, 293-321.

Gushiken, T., 2012. My Favorite Number is the Color Green: Implementing Green Walls in a Residential Setting to Improve Childhood Development. Doctor of Architecture Thesis: University of Hawai'i.

Hagerhall, C.M., 2000. Clustering predictors of landscape preference in the traditional swedish cultural landscape: prospect-refuge, mystery, age and management. Journal of Environmental Psychology, 20, 83-90.

Hartig, T., Evans, G., Jamner, L., Davis, D. \& Garling, T., 2003. Tracking restoration in natural and urban field settings. J Environ Psychol, 23, 109 - 123.

Hartig, T., Mitchell, R., De Vries, S. and Frumkin, H., 2014. Nature and health. Annual Review of Public Health, 35, 207-228.

Jamaludin, A.A., Keumala, N., Ariffin, A.R.M. \& Hussein, H., 2013. Satisfaction and perception of residents towards bioclimatic design strategies: Residential college buildings. Indoor and Built Environment, 23, 933-945.

Joarder, M., Price, A. \& Mourshed, M., 2010. Access to daylight and outdoor views: A comparative study for therapeutic daylighting design. World Health Design, 3, 62-69. 
Jorgensen, A. \& Gobster, P.H., 2010. Shades of green: measuring the ecology of urban green space in the context of human health and well-being. Nature and Culture, 5, 338-363.

Joye, Y., 2007. Fractal architecture could be good for you. Nexus Network Journal, 9, 311.

Kellert, S.R. 2005. Building for Life. Washington D.C: Island Press.

Kellert, S.R \& Calabrese, E., 2015. The Practice of Biophilic Design. e-book: Biophilic-Design.

Kellert, S.R., Heerwagen, J.H. \& Mador, M.L., 2008. Biophilic Design. New Jersey: John Wiley \& Sons.

Kellert, S.R. \& Wilson, E.O. 1993. The Biophilia Hypothesis, Washington D.C., Island Press.

Kerski, J.J., 2015. Geo-awareness, geo-enablement, geotechnologies, citizen science, and storytelling: geography on the world stage. Geography Compass, 9, 14-26.

Knudsen, A., 2017. Biophilic Phoenix: Growing the biophilic movement in the valley of the sun. Biophilic Cities Journal, September, 68-71.

Kuo, F.E. \& Sullivan, W.C., 2001. Environment and crime in the inner city: Does vegetation reduce crime? Environment and Behavior, 33, 343-367.

Landis, B. 1975. Fromm's theory of biophilia-necrophilia. Contemporary Psychoanalysis, 11, 418-434.

Lee, A.C.K., Jordan, H.C. \& Horsley, J. 2015. Value of urban green spaces in promoting healthy living and wellbeing: Prospects for planning. Risk Management and Healthcare Policy, 8, 131.

Lee, A.C.K. \& Maheswaran, R., 2011. The health benefits of urban green spaces: A review of the evidence. Journal of Public Health, 33, 212-222.

Li, Q., Otsuka, T., Kobayashi, M., Wakayama, Y., Inagaki, H., Katsumata, M., Hirata, Y., Li, Y., Hirata, K. \& Shimizu, T., 2011. Acute effects of walking in forest environments on cardiovascular and metabolic parameters. European Journal of Applied Physiology, 111, 2845-2853.

Louv, R. 2008. Last Child in the Woods: Saving our Children From Nature-Deficit Disorder. Chapel Hill, NC: Algonquin Books.

Matz, J.C., Stieb, M.D., Davis, K., Egyed, M., Rose, A., Chou, B. \& Brion, O., 2014. Effects of age, season, gender and urban-rural status on time-activity: Canadian Human Activity Pattern Survey 2 (CHAPS 2). International Journal of Environmental Research and Public Health, 11.

McIntosh, J., Marques, B. \& Hatton, W., 2018. Indigenous Cultural Knowledge for Therapeutic Landscape Design. In R. Isabel De Sousa, L. Joana Corte, R. Ricardo \& M. Ana (eds.). Handbook of Research on Methods and Tools for Assessing Cultural Landscape Adaptation. Hershey, PA: IGI Global, 28-52.

Melemis, S. and N. Tixier, 2014. Urban transects, ARCC/EAAE annual conference, Washington DC.

Millennium Ecosystem Assessment, 2005. Ecosystems and Human Well-Being: Synthesis. Washington DC: Island Press.

Mitchell, D., Tippins, D.J., Kim, Y.A., Perkins, G.D. \& Rudolph, H.A., 2016. Last Child in the Woods. In M. Powietrzynska \& K. Tobin (eds.). Mindfulness and Educating Citizens for Everyday Life. Rotterdam: SensePublishers, 135-158.

Nichols, W.J., 2014. Blue Mind: The Surprising Science that Shows how Being Near, In, On, or Under Water can Make You Happier, Healthier, More Connected, and Better at What You Do. Boston, UK: Little Brown and Company.

Norberg, J., Urban, M. C., Vellend, M., Klausmeier, C. A. \& Loeuille, N. 2012. Eco-evolutionary responses of biodiversity to climate change. Nature Clim. Change, 2, 747-751.

Olgyay, V., 2015. Design with Climate: Bioclimatic Approach to Architectural Regionalism. Princeton: Princeton University Press.

Pedersen Zari, M., R. Whale, M. de Roiste, E. Cruz, and K. Milne. 2017. Wellington Nature in the City Map. Online: Wellington City Council. Accessed October 2019. http://vuw.maps.arcgis.com/apps/MapJournal/index.html?appid=2d50a148a59748a99de1830a3122d9

Pedersen Zari, M., 2017. What makes a city 'biophilic'? Observations and experiences from the Wellington Nature Map project. Back to the future: The next 50 years, 51st International Conference of the Architectural Science Association, Wellington, New Zealand, 29 November - 1 December.

Pedersen Zari, M., 2018. Regenerative Urban Design and Ecosystem Biomimicry. Oxon: Routledge

Potschin, M. \& Haines-Young, R., 2016. Defining and measuring ecosystem services. In Potschin, M., HainesYoung, R., Fish, R., Turner, R.K. (eds.). Routledge Handbook of Ecosystem Services. London and New York: Routledge, 25-44. 
Rastandeh, A., Pedersen Zari, M., K. Brown, D. \& Vale, R., 2018. Utilising exotic flora in support of urban indigenous biodiversity: lessons for landscape architecture. Landscape Research, 43, 708-720.

Rink, D. \& Emmrich, R., 2005. Surrogate nature or wilderness? Social perceptions and notions of nature in an urban context. In Kowarik I. and Körner S. (eds.). Wild Urban Woodlands. Berlin, Heidelberg: Springer, 67-80.

Ruebush, M., 2009. Why dirt is good: 5 ways to make germs your friends: Kaplan Publishing.

Ryan, C.O., Browning, W.D., Clancy, J.O., Andrews, S.L. \& Kallianpurkar, N.B., 2014. Biophilic design patterns: Emerging nature-based parameters for health and well-being in the built environment. International Journal of Architectural Research: ArchNet-IJAR, 8, 62-76.

Samson, R., Grote, R., Calfapietra, C., Cariñanos, P., Fares, S., Paoletti, E. \& Tiwary, A., 2017. Urban Trees and Their Relation to Air Pollution. In D. Pearlmutter et al. (eds.). The Urban Forest. Cham: Springer, 2130 .

Sangha, K.K., Preece, L., Villarreal-Rosas, J., Kegamba, J.J., Paudyal, K., Warmenhoven, T. \& Ramakrishnan, P. 2018. An ecosystem services framework to evaluate Indigenous and local peoples' connections with nature. Ecosystem services, 31, 111-125.

Sangha, K.K., Russell-Smith, J. \& Costanza, R., 2019. Mainstreaming indigenous and local communities' connections with nature for policy decision-making. Global Ecology and Conservation, 19, e00668.

Soderlund, J. \& Newman, P., 2015. Biophilic architecture: A review of the rationale and outcomes. AIMS Environmental Science, 2, 950-969.

Soga, M. \& Gaston, K.J., 2016. Extinction of experience: The loss of human-nature interactions. Frontiers in Ecology and the Environment, 14, 94-101.

Sui, D.Z. \& Cinnamon, J., 2016. Spaces and Places: Engaging a Mixed-methods Approach for Exploring the Multiple Geographies of Pedestrian Injury. In M.D. Giesbrecht and V.A. Crooks (eds.). Place, Health, and Diversity. London: Routledge, 96-118.

Taylor, L. \& Hochuli, D.F., 2015. Creating better cities: How biodiversity and ecosystem functioning enhance urban residents' wellbeing. Urban Ecosystems, 18, 747-762.

Taylor, R.P., 2006. Reduction of physiological stress using fractal art and architecture. Leonardo, 39, $245-251$.

Turner, W.R., Nakamura, T.\& Dinetti, M., 2004. Global urbanization and the separation of humans from nature. BioScience, 54, 585-590.

Tyrväinen, L., Ojala, A., Korpela, K., Lanki, T., Tsunetsugu, Y. \& Kagawa, T., 2014. The influence of urban green environments on stress relief measures: A field experiment. Journal of Environmental Psychology, 38, 1-9.

Ulrich, R., 1984. View through a window may influence recovery from surgery. Science, 224, 4647.

Viljoen, A. \& Howe, J., 2012. Continuous Productive Urban Landscapes: Oxford: Routledge.

Waterfront Leadership Group, 2001. The Wellington Waterfront Framework. Wellington: Wellington City Council.

Wellington City Council, 2003. Wellington's Outer Green Belt Management Plan. Wellington: Wellington City Council, 177.

Wilson 1984. Biophilia. The Human Bond with Other Species. Cambridge: Harvard University Press.

Yeang, K., Balfour, A., Richards, I. \& Hamzah, T.R., 1994. Bioclimatic Skyscrapers: London: Artemis.

Zhang, X.Q., 2016. The trends, promises and challenges of urbanisation in the world. Habitat International, 54, 241-252.

Zupancic, T., Westmacott, C. \& Bulthuis, M., 2015. The Impact of Green Space on Heat and Air Pollution in Urban Communities: A Meta-Narrative Systematic Review: Vancouver: David Suzuki Foundation. 